\title{
ALGAL VEGETATIVE ACTIVITY IN THE UPPER JORDAN RIVER (NORTHERN ISRAEL): AN IN VITRO GLASS SLIDE EXPERIMENT
}

\author{
LIPKOVSKY, E. - BARINOVA, S.* - NEVO, E. \\ The Algology Laboratory in the Institute of Evolution, University of Haifa \\ Mount Carmel, Haifa 31905, Israel \\ (phone: +972-4-8249697; fax: +972-4-8246554) \\ *Corresponding author \\ e-mail: barinova@research.haifa.ac.il \\ (Received $25^{\text {th }}$ April 2008; accepted $8^{\text {th }}$ July 2011)
}

\begin{abstract}
Algal vegetative activity and intensity of self purification processes were determined via a two stage in vitro artificial substrates (glass slides) occupation experiment, conducted during winter 20062007 and summer 2007 in the streams of the Upper Jordan River Basin. Daily measurement of temperature, conductivity, mineralization and $\mathrm{pH}$ were performed. Once a week algal species where identified, snd their Abundance (cells $/ \mathrm{cm}^{2}$ ), Cell volumes $\left(\mu \mathrm{m}^{3} / \mathrm{cm}^{2}\right.$ ) and richness of species (taxa encountered/600 algal cells) tabulated for each taxon. Algal communities where richer in the summer in all stations and contained mainly Diatoms or Diatoms/green algae mix. Only the Banias station winter community was dominated by the green algae. Highest self-purification activity was observed during the summer in the upper part of the basin (Banias station). Species richness grew with anthropogenic influence and self-purification intensity. Self-purification proceeded faster in conditions of high temperature and solar radiation. The Shannon index positively correlated with species richness in both winter and summer experiments. The artificial colonization of substrates by algae took 2-3 weeks; formation of small celled green algae encouraged by high temperatures and solar radiation conditions increased colonization speed in the summer. Statistically significant factors influencing algal activity were found to be $\mathrm{pH}$ and Total Dissolved Solids concentration.
\end{abstract}

Keywords: Upper Jordan River, artificial substrate, in vitro experiment, season, Israel

\section{Introduction}

The Upper Jordan River is the major source of fresh water feeding Lake Kinneret. Therefore its water must be of sufficient quality.

The surface water quality is determined by loads penetrating the water basin, as well as the intensity in which self-purification processes occur. Algae serve as the first element in the nutrients utilization process and in small rivers they develop on substrates.

The intensity of the self-purification process is directly linked to the amount of nutrients and the speed of their utilization. Within the water monitoring framework in countries of the European Union, periphyton in the rivers is monitored (European Parliament, 2000). For this purpose, the species content, presence of indicator species, abundance, species biomass in the community as well as chlorophyll concentrations were determined (Cardoso et al., 2005).

Observations of substrate occupation are recommended during the vegetation period (Ács et al., 2005). In the Upper Jordan River basin algae developed more actively during the rainy season (December-March). In order to make any conclusion regarding to the intensity of these processes, it was essential to determine the attributes of four general classes: (1) taxonomic composition, (2) species richness and diversity, (3) 
tolerance/intolerance, and (4) trophic structure (King and Richardson, 2003). Referring to the first three classes we previously assessed the algal diversity in the Upper Jordan River basin on the basis of our data base (Barinova et al., 2006).

A two stage experiment for the determination of algal vegetative activity in the streams of the Upper Jordan River Basin was conducted during December-January 2006-2007 and September-October 2007. Via this study we determined the speed at which colonization of substrates occurs and the activity levels of self purification processes at different stations of the Upper Jordan River Basin.

\section{Materials and methods}

Each stage of the experiment was conducted in vitro on artificial substrates. Water samples (each of 301 volume) as well as substrates and algae samples where collected from the habitats at the sampling stations in the Upper Jordan River area (Fig. 1). For each sampling station the collected water, substrates and algae where mixed together in a plastic container of 501 volume. The pool shaped containers where placed on the roof of one of the buildings in Haifa University.

Daily measurement of temperature, conductivity, mineralization and $\mathrm{pH}$ were performed using the HANNA HI 9813 apparatus and a thermometer. Nitrates concentration in each pool was determined via the HANNA HI 93728 apparatus at stage 1 and by a specialized water laboratory (The Neve Yaar field laboratory) at stage 2. Glass slides served as the artificial substrates. They where placed horizontally in parallel to the water surface on buoys at $5 \mathrm{~cm}$ depth (Ács et al., 2005).

Each 7 days slides where collected from all the pools to determine the present algal species, their abundance/number and algal biomass on each slide.

The identification of algal species on the sufrace of the glass slides was performed using a dissecting Swift microscope under magnifications of 800. Cell counting for each species was performed via the direct counting method.

To simplify calculating periphyton algae we made sure the encrustation grew on a flat surface of a known area (PhycoTech, 2007).

Abundance $\left(\right.$ cells $\left./ \mathrm{cm}^{2}\right)$, Cell volumes $\left(\mu \mathrm{m}^{3} / \mathrm{cm}^{2}\right.$ ) and Species richness (taxa encountered/600 algal cells) where tabulated for each taxon (Charles et al., 2002). For each sampling slide cell counting was performed in numerous view fields until at least 600 cells were enumerated. The counting of each field $(330 \times 330 \mu \mathrm{m})$ was repeated for 10-100 times for each species and the average was registered. Average cell volume was estimated by measuring the dimensions of at least 30 representative cells and calculating cell volume in accordance with the nearest geometric shape (Charles et al., 2002; Hillebrand et al., 1999). The obtained cell volumes where multiplied by the previously obtained cell numbers. Taxa without distinct cell walls and certain colonial algae (e.g. Cyanobacteria) were counted as colony operational units.

Since in our experiment we have counted the number of individuals of each species in the present community we were able to calculate the Shannon index $H$ ' which reflects the degree of abundance equality among the species in the community and is correlated to the entropy of the ecosystem (Good, 1953). The non-parametric Shannon index is calculated as follows:

$$
\mathrm{H}^{\prime}=-\sum_{\mathrm{i}=1}^{\mathrm{S}} \frac{\mathrm{n}_{\mathrm{i}}}{\mathrm{N}} \ln \frac{\mathrm{n}_{\mathrm{i}}}{\mathrm{N}}
$$


where:

$n_{i}$ - Number of individuals in each species;

$\mathrm{S}-\mathrm{The}$ number of species: species richness;

$\mathrm{N}$ - Total number of all individuals;

$\frac{n_{i}}{N}-$ Relative abundance of each species.

\section{Results and discussion}

During the experimental periods water temperatures ranged between: $24.6-29.3^{\circ} \mathrm{C}$ (at times reaching $32^{\circ} \mathrm{C}$ ) in the summer and between $13-19^{\circ} \mathrm{C}$ (at times reaching $11^{\circ} \mathrm{C}$ ) in the winter (Table 1).

Table 1. Summary of parameters for all sampling stations during the four weeks of both summer and winter experiments.

\begin{tabular}{|c|c|c|c|c|c|c|c|c|}
\hline \multicolumn{9}{|c|}{ Banias } \\
\hline \multirow{2}{*}{$\begin{array}{c}\text { Day of } \\
\text { Experiment }\end{array}$} & \multicolumn{2}{|c|}{ TDS (mg/l) } & \multicolumn{2}{|c|}{ pH } & \multicolumn{2}{|c|}{ Temperature ${ }^{\circ} \mathrm{C}$} & \multicolumn{2}{|c|}{$\mathrm{NO}_{3}(\mathrm{mg} / \mathrm{l})$} \\
\hline & Winter & Summer & Winter & Summer & Winter & Summer & Winter & Summer \\
\hline 7 & 295 & 234 & 7 & 7.6 & 15 & 28.8 & 0 & 1.2 \\
\hline 14 & 333 & 211 & 8.1 & 7.35 & 19 & 29.1 & 0 & 0.9 \\
\hline 21 & 224 & 214 & 8.2 & 8.1 & 13 & 24.7 & 0 & 0.7 \\
\hline 28 & 123 & 246 & 6.4 & 7.9 & 13 & 26.1 & 0 & 0 \\
\hline \multicolumn{9}{|c|}{ Yosef } \\
\hline Day of & \multicolumn{2}{|c|}{ TDS (mg/l) } & \multicolumn{2}{|c|}{ pH } & \multicolumn{2}{|c|}{ Temperature ${ }^{\circ} \mathrm{C}$} & \multicolumn{2}{|c|}{$\mathrm{NO}_{3}(\mathrm{mg} / \mathrm{l})$} \\
\hline Experiment & Winter & Summer & Winter & Summer & Winter & Summer & Winter & Summer \\
\hline 7 & 213 & 158 & 7.45 & 7.7 & 15 & 28.6 & 0.2 & 1.6 \\
\hline 14 & 246 & 178 & 7.8 & 7.5 & 19 & 28.9 & 0 & 0.9 \\
\hline 21 & 197 & 193 & 8.1 & 7.85 & 13 & 24.7 & 0 & 0 \\
\hline 28 & 132 & 200 & 6.6 & 7.8 & 13 & 26.4 & 0 & 0 \\
\hline
\end{tabular}

Jordan

\begin{tabular}{c|cc|cc|cc|cc} 
Day of & \multicolumn{2}{|c|}{ TDS (mg/l) } & \multicolumn{2}{c|}{$\mathbf{p H}$} & \multicolumn{2}{c|}{ Temperature ${ }^{\circ} \mathbf{C}$} & \multicolumn{2}{c}{$\mathbf{N O}_{\mathbf{3}}(\mathbf{m g} / \mathbf{l})$} \\
\hline Experiment & Winter & Summer & Winter & Summer & Winter & Summer & Winter & Summer \\
\hline 7 & 213 & 193 & 7.45 & 7.8 & 15 & 26.5 & 0.2 & 0.2 \\
14 & 246 & 166 & 7.8 & 7.65 & 19 & 28.8 & 0 & 0 \\
21 & 197 & 217 & 8.1 & 7.8 & 13 & 24.6 & 0 & 0 \\
28 & 132 & 186 & 6.6 & 7.8 & 13 & 26.2 & 0 & 0 \\
\hline
\end{tabular}

Meshushim

\begin{tabular}{c|cc|cc|cc|cc} 
Day of & \multicolumn{2}{|c|}{ TDS (mg/l) } & \multicolumn{2}{c|}{$\mathbf{p H}$} & \multicolumn{2}{c|}{ Temperature ${ }^{\circ} \mathbf{C}$} & \multicolumn{2}{c}{$\mathbf{N O}_{\mathbf{3}}(\mathbf{m g} / \mathbf{l})$} \\
\hline Experiment & Winter & Summer & Winter & Summer & Winter & Summer & Winter & Summer \\
\hline 7 & 276 & 241 & 8 & 8.8 & 15 & 28.7 & 0 & 1.9 \\
14 & 295 & 252 & 8.8 & 8.2 & 19 & 29.3 & 0 & 1.1 \\
21 & 201 & 261 & 7.5 & 7.7 & 15 & 25.1 & 0 & 0.4 \\
\hline 28 & 139 & 217 & 7 & 7.7 & 13 & 26.6 & 0 & 0 \\
\hline
\end{tabular}


As it can be seen in the Table 1, in both experiments at the beginning the highest water acidity was observed in the Banias stream, while the most alkali water was observed in the Meshushim stream. Acidity of the Yosef bridge waters closely resembled those of the Jordan River but, tended to be more neutral.

At the end of the winter experiment the $\mathrm{pH}$ in all pools was $\leq 7.0$. The summer final $\mathrm{pH}$ values on the other hand where much more alkali and came close to 8.0 .

There was no rain fall during the entire summer experiment period. Whereas during the winter experiment there was rain fall each 5-7 days as common in the north of Israel.

During the winter experiment in each of the experimental pools we have observed a tendency of TDS lowering towards the $4^{\text {th }}$ week, with final values being about half those we have started with (Table 1). This points to a demineralization process that could be related to the activity of the algal communities. During the summer experiment we have observed a peak in the TDS values on the third week in the Jordan and Meshushim stations and on the forth week in the Banias and Yosef stations. The dynamics of Mineralization values is related to the self-purification processes. The overall TDS values during the entire experiment remained low which indicates the general purity of water in our experimental stations.

Nitrates can serve as indicators of both water quality and the activity level of the algal community. In Table 1, we see that in the winter experiment very low amounts of nitrates where present at the Yosef and Jordan stations.

However during the summer experiment nitrates were present in all stations (with maximal initial concentration observed at the Meshushim station) but lowered with time. This shows that in the winter water is cleaner and the algal communities are more active.

Comparing winter and summer results in the Banias station (Fig. 2) the general range of both abundance and biomass were similar during both experimental periods. Yet in the winter experiment the average cell volume (biomass) was almost twice that of the one found in the summer experiment. This points to the difference in stress factors during the two periods being much higher during the summer time. Cells were smaller in the summer as a result of environmental stress influences. The trend lines are in agreement with these conclusions.

Comparison of algal abundance and biomass in the Yosef station (Fig. 3) shows that while the abundance remains about the same in both periods, cell biomass was four times higher during the summer period. Average cell volume during the first three weeks of both experiments where somewhat similar; however, on the fourth week of the summer experiment the average cell volume increased tremendously suggesting the stress factor influence subsided. All trend lines show opposite tendencies in each of the factors during winter as opposed to summer.

At the Jordan station during both experiments (Fig. 4) both abundance and biomass where somewhat higher during summer. Since average cell volume fluctuated in the winter experiment while, remaining constantly small during the summer period, we can say that a higher level of stress factors influenced the system during the summer period. The trend lines confirm similar tendencies for all factors except abundance for which they are opposite in the winter and the summer. 


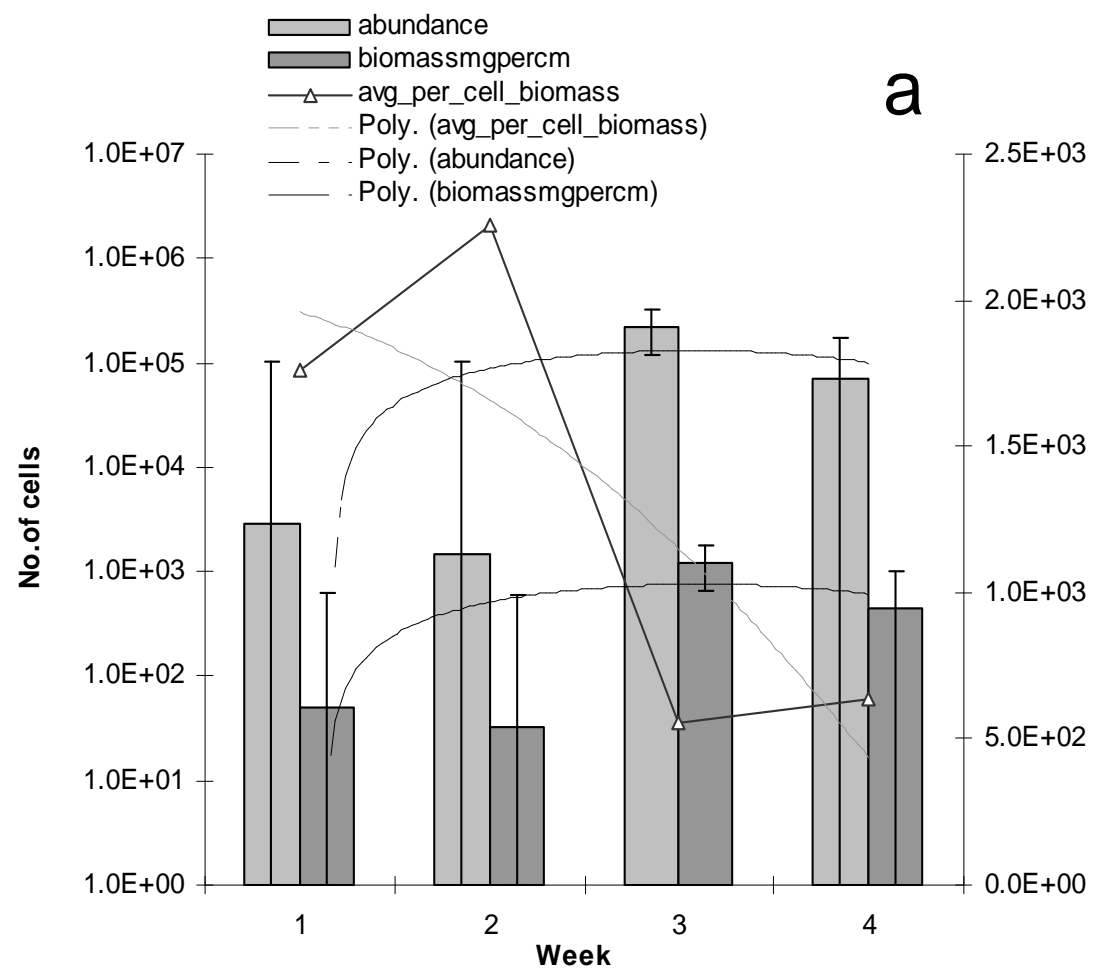

ֻू

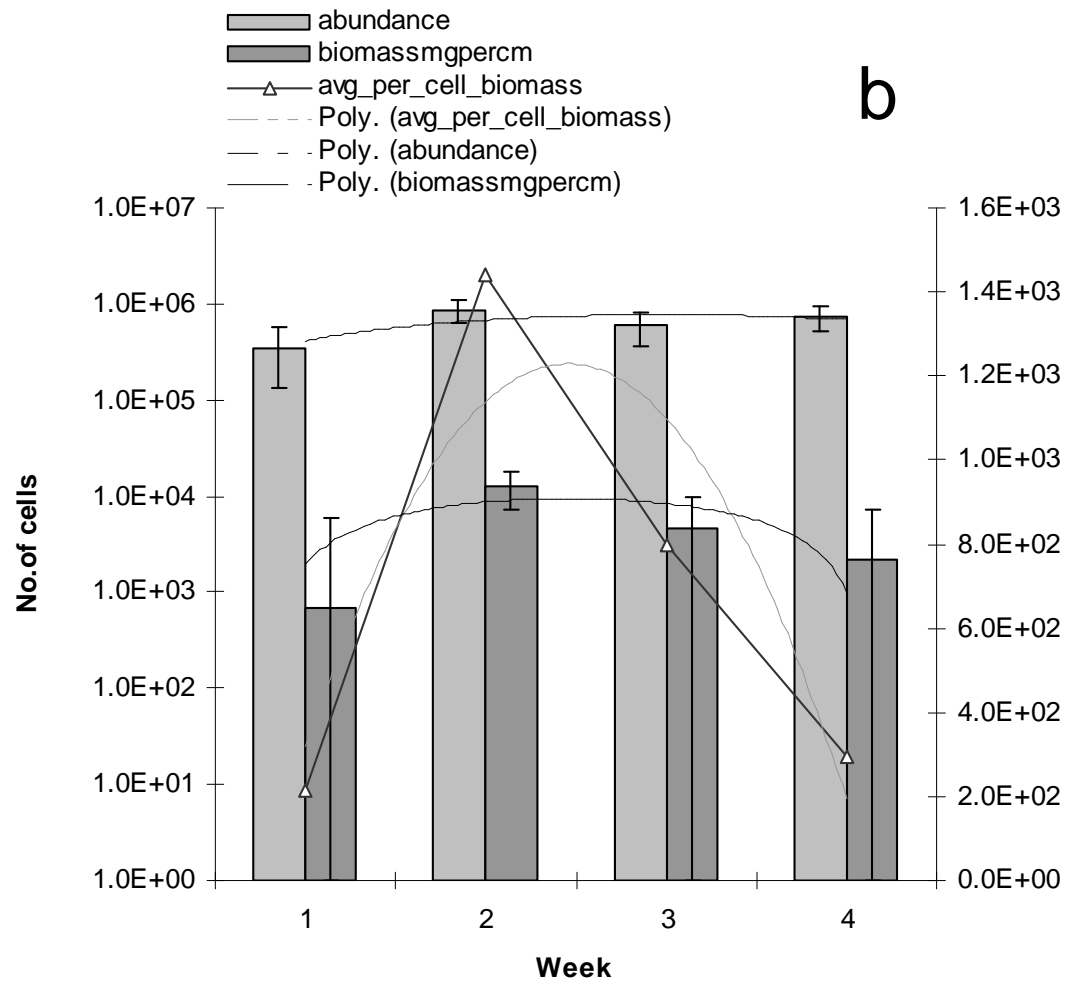

Figure 2. Changes in abundance biomass per $\mathrm{cm}^{2}$ average cell biomass during the summer and winter experimental periods in the Banias station - a: winter; $b$ : summer 

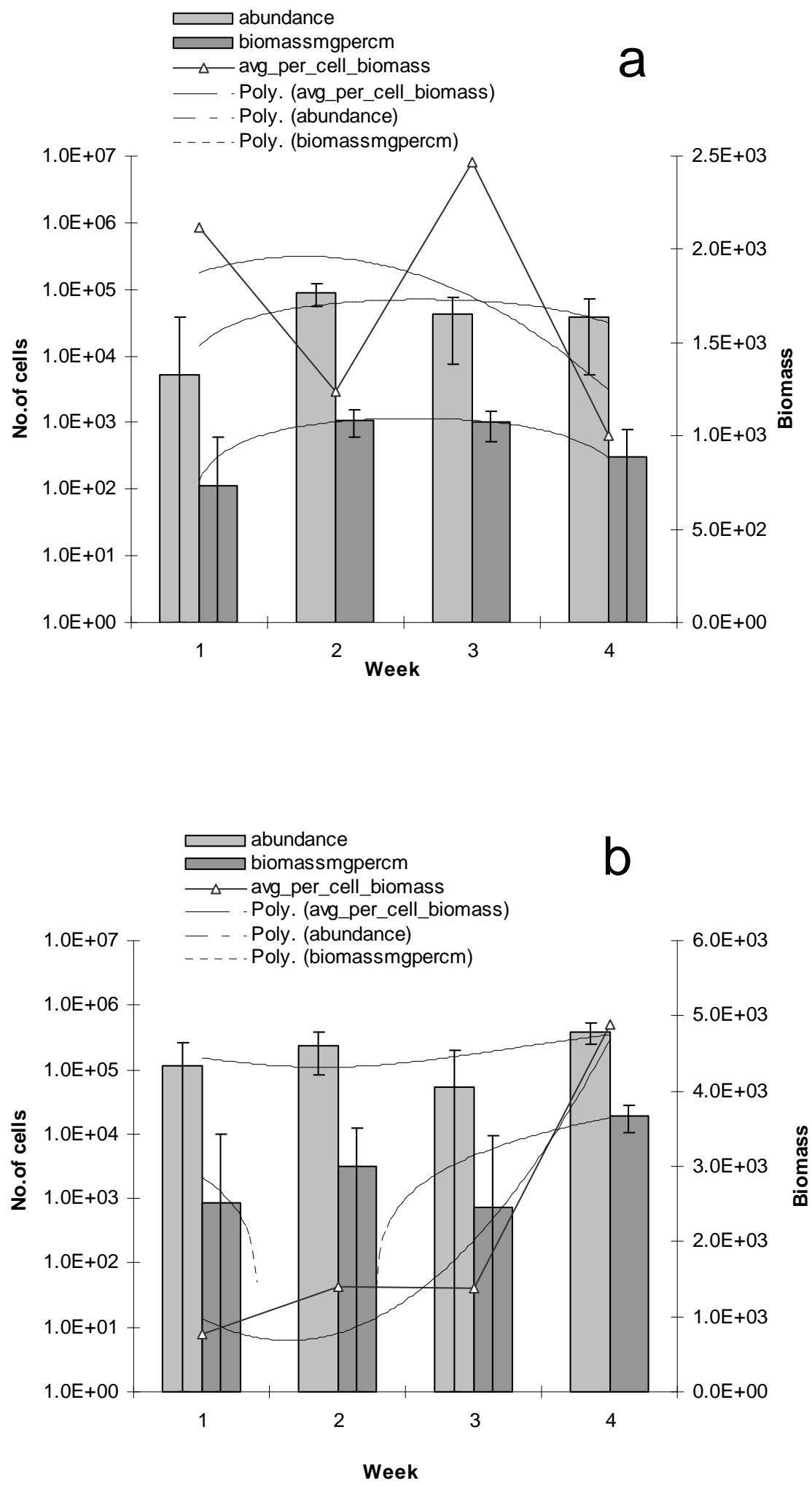

Figure 3. Changes in abundance biomass per $\mathrm{cm}^{2}$ average cell biomass during the summer and winter experimental periods at the Yosef station - $a$ : winter; $b$ : summer 


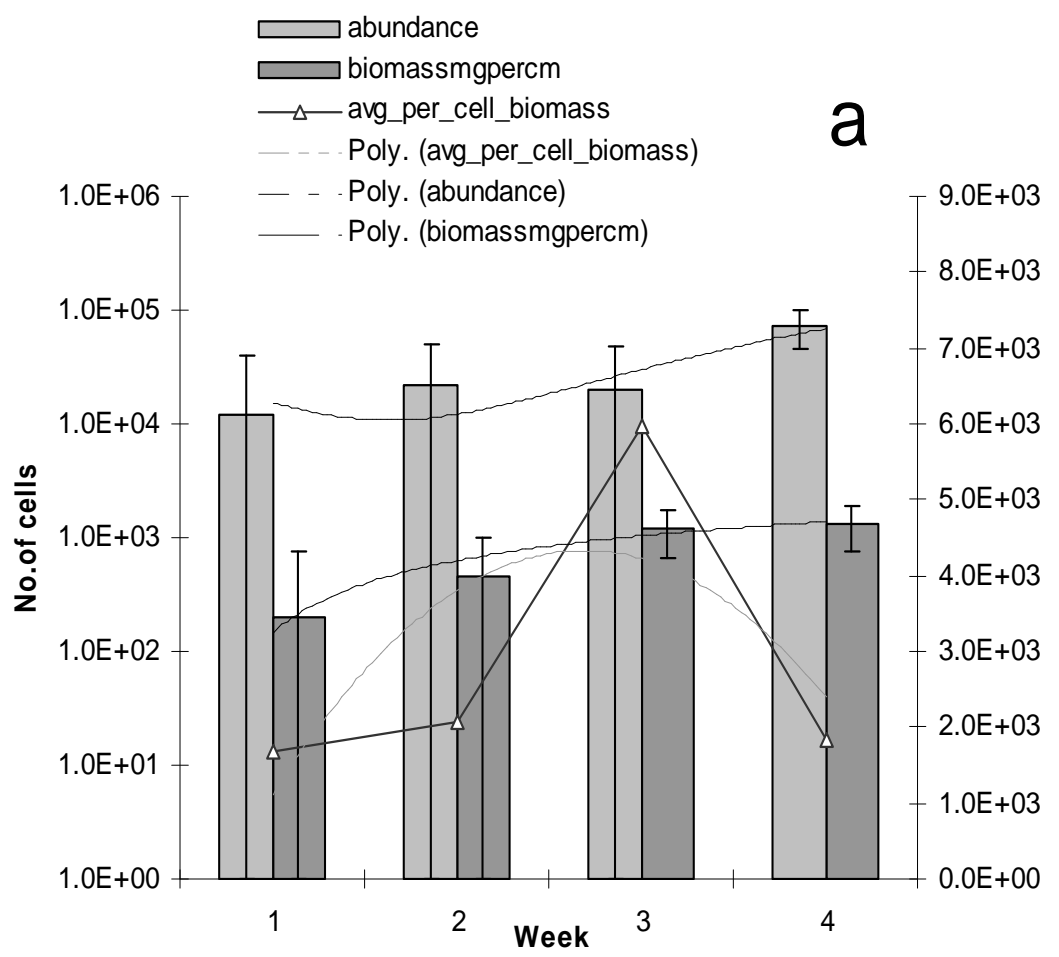

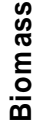

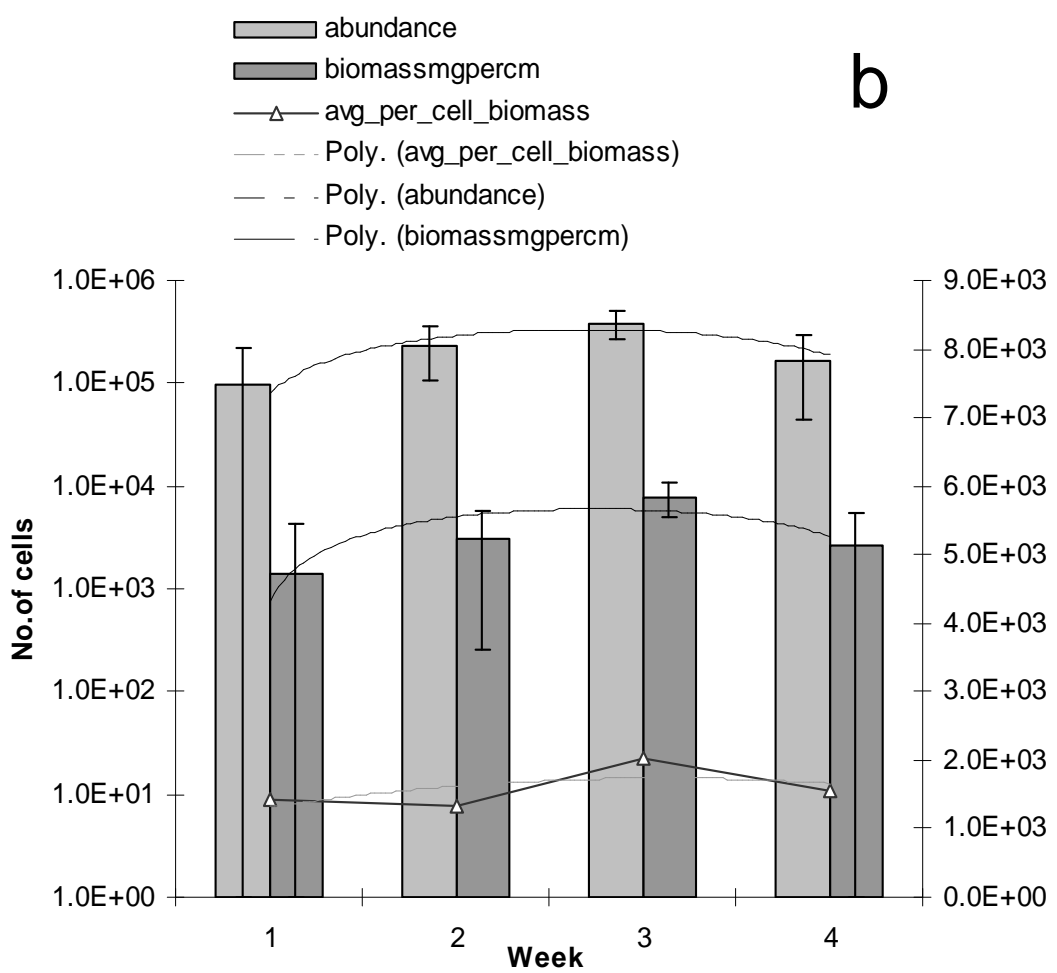

Figure 4. Changes in abundance biomass per $\mathrm{cm}^{2}$ average cell biomass during the summer and winter experimental periods at the Jordan station - $a$ : winter; $b$ : summer 

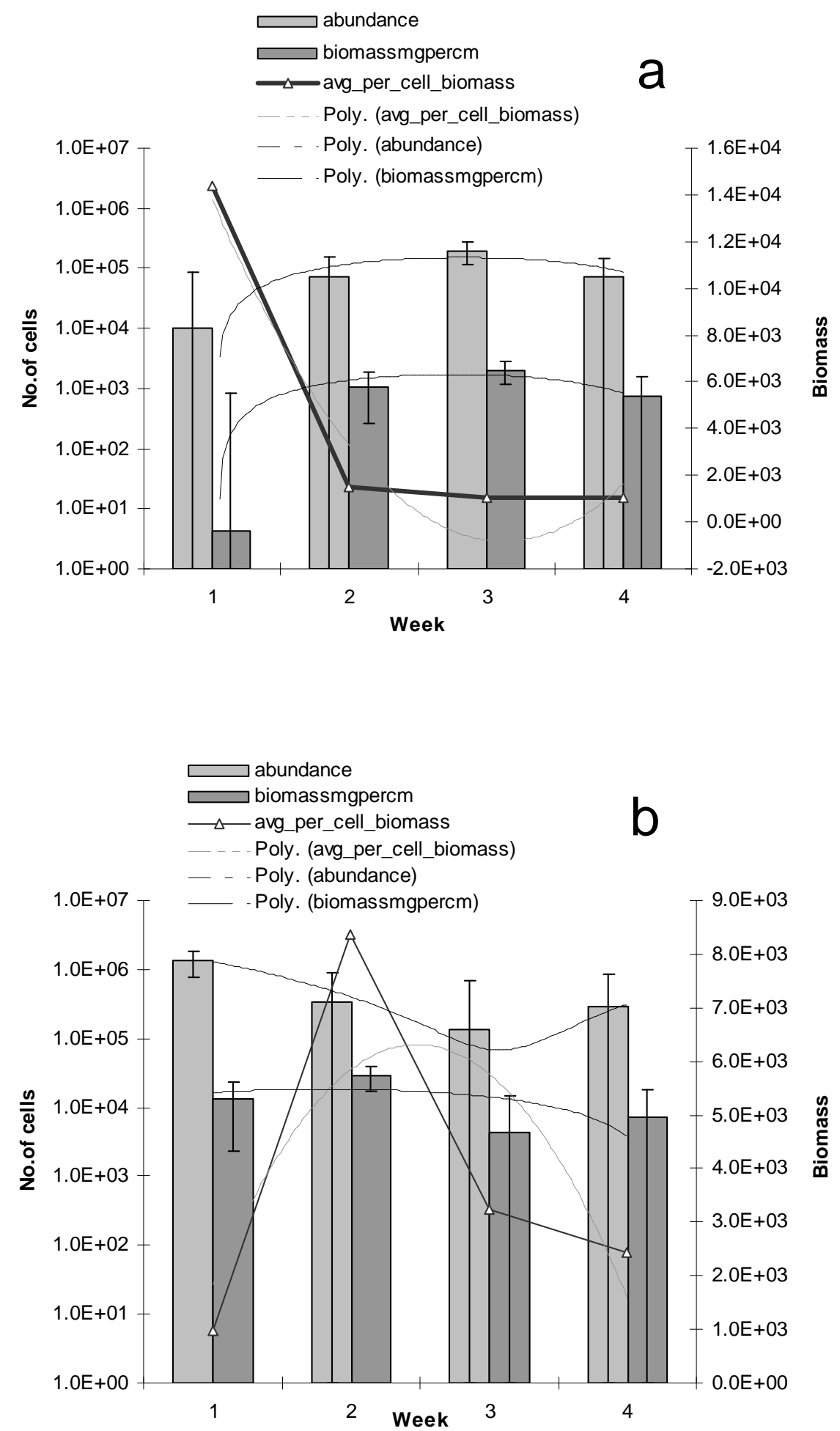

Figure 5. Changes in abundance biomass per $\mathrm{cm}^{2}$ average cell biomass during the summer and winter experimental periods at the Meshushim station - $a$ : winter; $b$ : summer 
At the Meshushim station (Fig. 5) abundance during the summer period was ten times higher; however, the biomass remained in the same range during both experiments. The average cell volume in the summer was ten times lower than in the winter.

These results suggest that there are stress impacts in the system during the summer. The trend lines confirm similar changes during the experiment for all factors except for the average cell volume for which they are opposite.

At the Banias station the total number of species during both experimental periods was about the same, under 20 species in total (Fig. 6). However, the diversity of the community in the Banias station was the richest among all stations. The Banias station diversity peak was achieved on the third week of the winter experiment and was mostly due to green algae species. At the same time the maximal diversity during the summer experiment was obtained already on the second week and was mostly composed of diatoms as well as green algae.

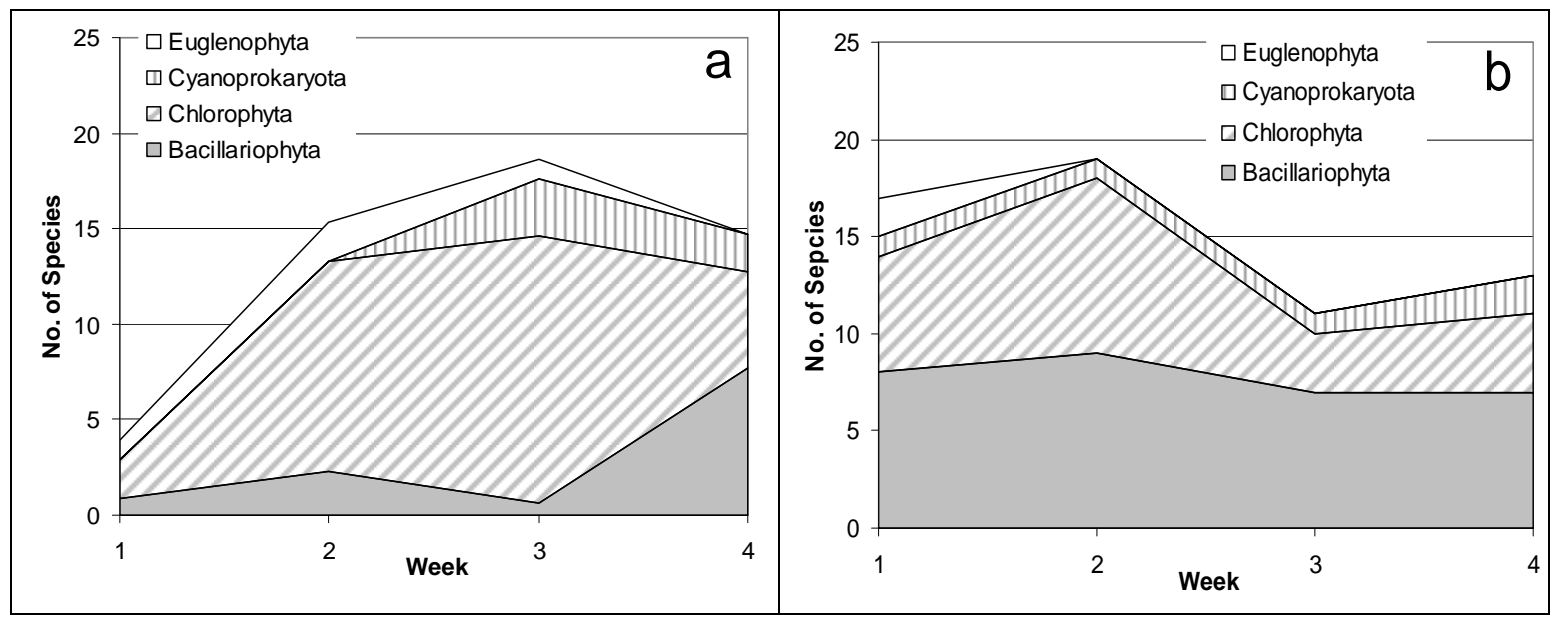

Figure 6. Divisional and numeric changes in the community of species during the summer and winter experimental periods at the Banias station - $a$ : winter; $b$ : summer

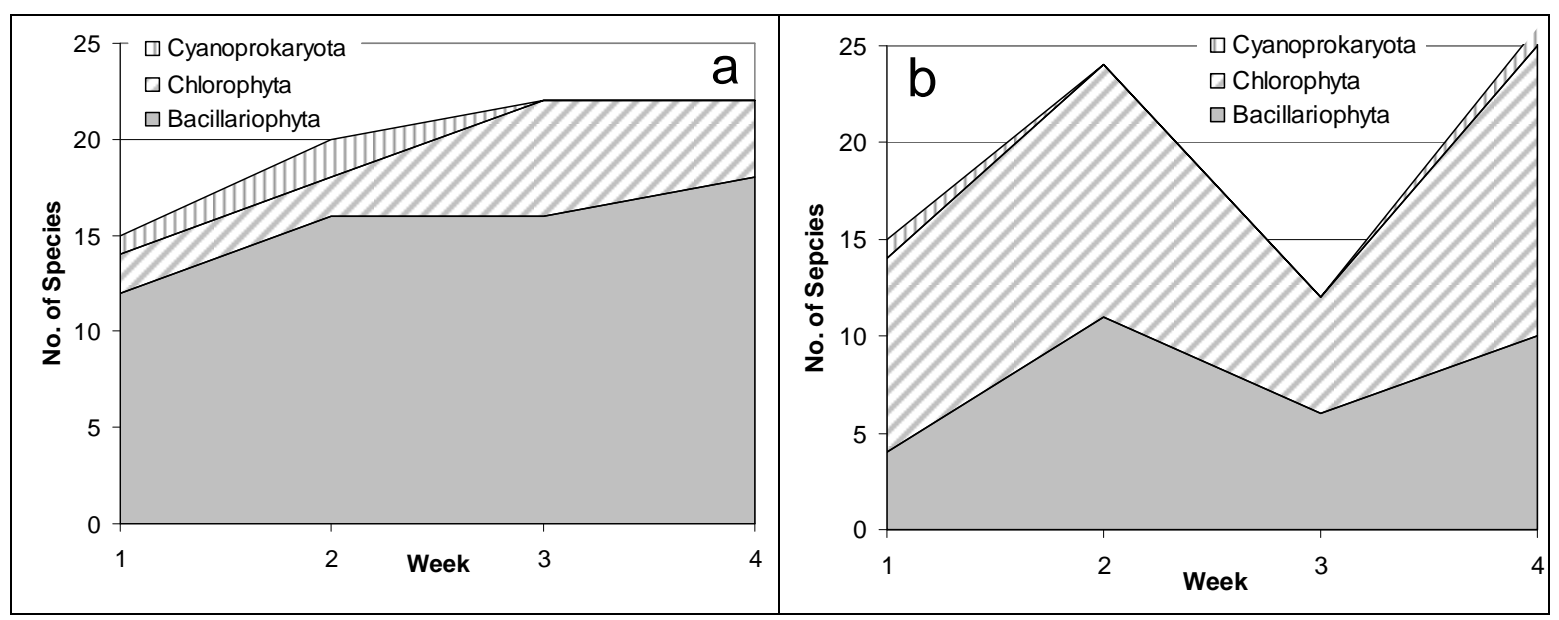

Figure 7. Divisional and numeric changes in the community of species during the summer and winter experimental periods at the Yosef station - a: winter; $b$ : summer 
Maximal species richness at the Yosef station was in the range of 20-25 species (Fig. 7). The winter community reached its peak on the third week mostly due to diatom species, while in the summer community the diversity fluctuated and had contained equal amounts of both diatoms and green algae.

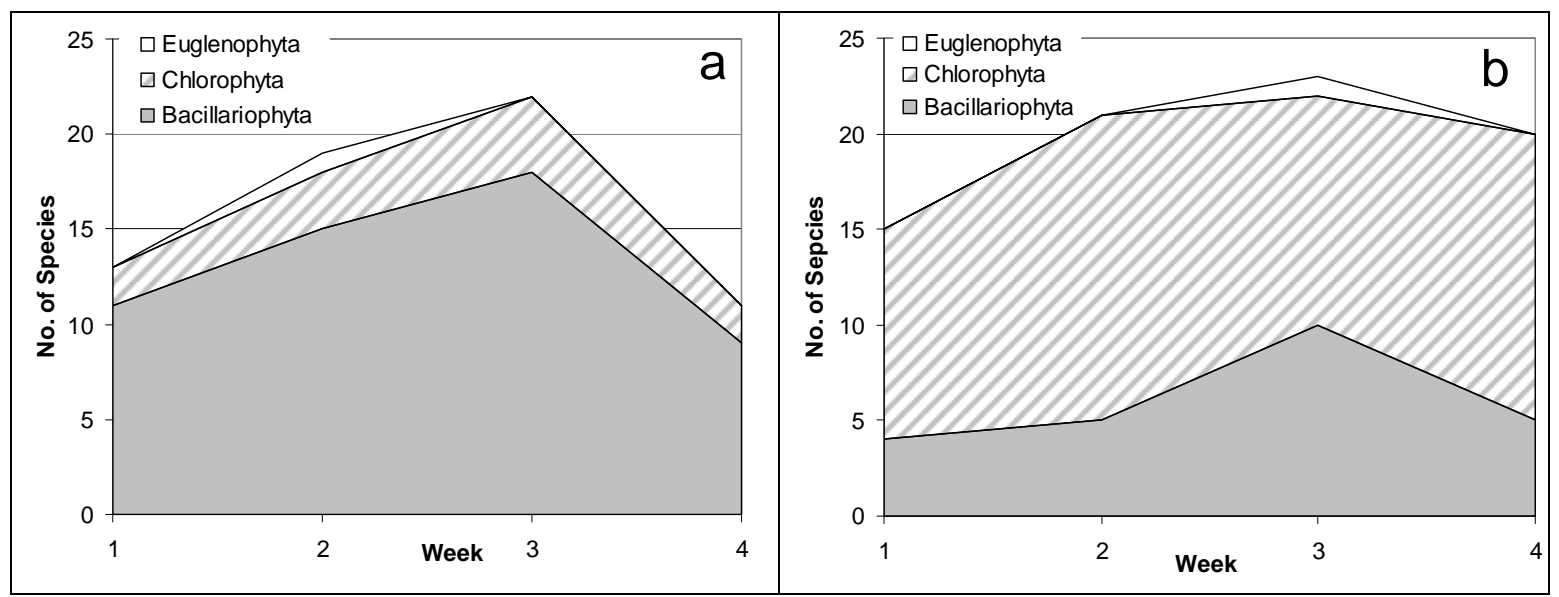

Figure 8. Divisional and numeric changes in the community of species during the summer and winter experimental periods at the Jordan station - a: winter; $b$ : summer

Maximal number of species at the Jordan station was reached on the third week of both experiments and ranged from 20-25 species (Fig. 8). Yet, the winter community was comprised mostly of diatoms while the summer community was dominated by green algae.

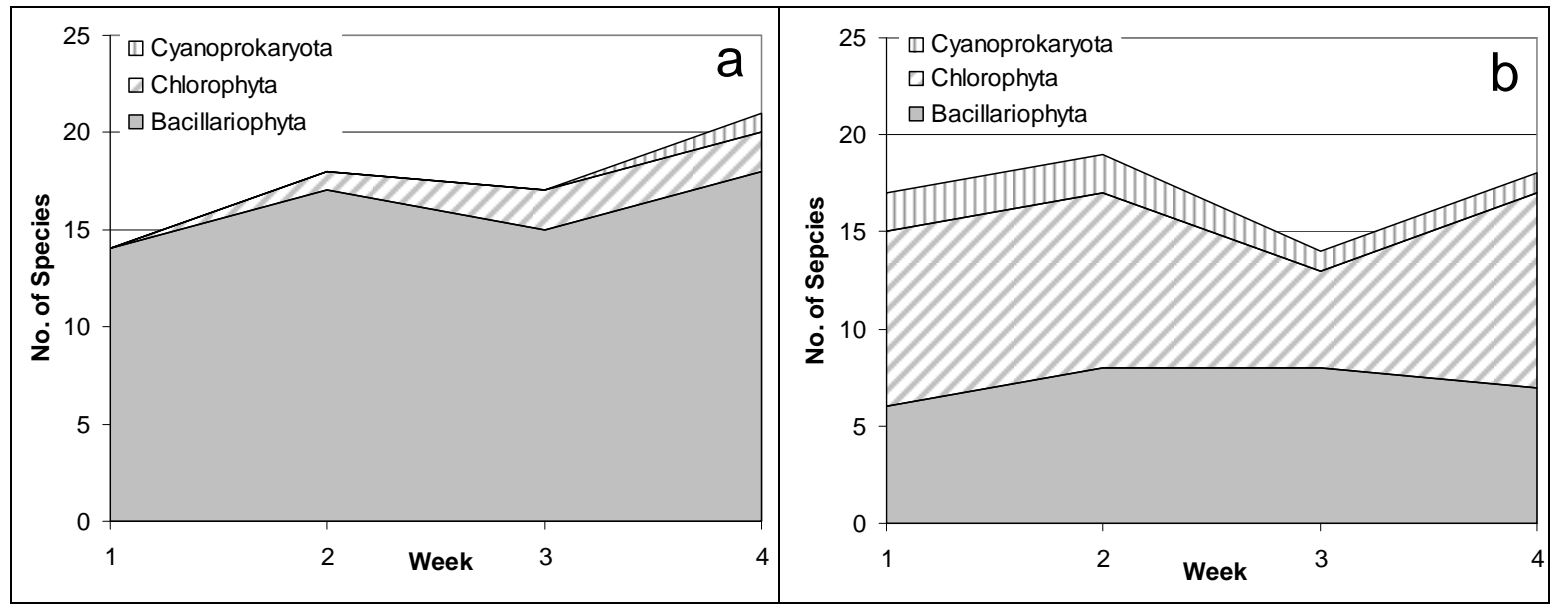

Figure 9. Divisional and numeric changes in community of species during the summer and winter experimental periods at the Meshushim station - $a$ : winter; $b$ : summer

The low diversity community of the Meshushim station reached its peak (21 species) in the winter period only on the fourth week mostly due to diatom species (Fig. 9). The summer community was about equally comprised of diatoms and green algae and during the entire period was enriched with cyanobacteria. The total low diversity as well as the presence of cyanobacteria during the summer period indicate a reaction of the Meshushim ecosystem to stress impacts. 
Table 2 shows that the factors positively influencing species richness in general and diatoms richness in particular, are $\mathrm{pH}$ and TDS. These factors have positive influence on the biomass as well.

Table 2. Multivariate regression stepwise statistical analysis results for the winter experiment in the entire Jordan Basin

\begin{tabular}{l|c|c|c|c|c}
\hline Winter basin & Step 1 & Step 2 & Step 3 & Step 4 & Step 5 \\
\hline No. of Species & - & pH TDS & - & - & - \\
Abundance & - & $0.57^{* *}$ & - & - & - \\
Biomass & - & - & TDS pH & & \\
Avg_per_cell_biomass & - & - & $0.35^{*}$ & - & - \\
Bacillariophyta & - & - & - & - & - \\
Chlorophyta & - & - & $0.34^{*}$ & - & - \\
\hline
\end{tabular}

Multivariate regression analysis of the summer communities in the entire upper Jordan basin in Table 3 shows that factors possessing very slight positive influence on the Chlorophyta species richness are TDS, temperature and Nitrate concentrations.

Table 3. Multivariate regression stepwise statistical analysis results for the summer experiment in the entire Jordan Basin

\begin{tabular}{l|c|c|c|c|c}
\hline Summer basin & Step 1 & Step 2 & Step 3 & Step 4 & Step 5 \\
\hline No. of Species & - & - & - & - & - \\
Abundance & - & - & - & - & - \\
Biomass & - & - & - & - & - \\
Avg_per_cell_biomass & - & - & - & - & - \\
Bacillariophyta & - & - & - & - & - \\
Chlorophyta & - & - & - & TDS Temp NO & \\
& - & - & $-504^{*}$ & - \\
\hline
\end{tabular}

Since the Meshushim station was found to be a point suffering from environmental stress impacts we have performed a Multivariate regression analysis on the data collected for this station in both the winter and summer experiments.

Table 4. Multivariate regression Stepwise statistical analysis combined results for the summer and winter experiment at the Meshushim station

\begin{tabular}{|c|c|c|c|c|c|}
\hline $\begin{array}{c}\text { Meshuhsim } \\
\text { Summer-Winter }\end{array}$ & Step 1 & Step 2 & Step 3 & Step 4 & Step 5 \\
\hline No. of Species & - & 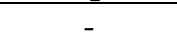 & - & 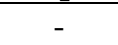 & - \\
\hline Abundance & $\begin{array}{c}\mathrm{NO}_{3} \\
0.77^{* *}\end{array}$ & - & - & - & - \\
\hline Biomass & $\begin{array}{l}\text { Temp } \\
0.52^{*}\end{array}$ & - & - & - & - \\
\hline Avg_per_cell_biomass & - & - & - & - & - \\
\hline Bacillariophyta & $\begin{array}{c}\text { Temp } \\
0.82 * *\end{array}$ & $\begin{array}{c}\text { Temp } \\
0.83^{* *}\end{array}$ & $\begin{array}{l}\text { Temp } \\
0.79^{*}\end{array}$ & - & - \\
\hline Chlorophyta & - & $\begin{array}{c}\text { Temp TDS } \\
0.95^{* * *}\end{array}$ & $\begin{array}{c}\text { Temp TDS } \\
0.94 * *\end{array}$ & $\begin{array}{l}\text { Temp } \\
0.93^{*}\end{array}$ & \\
\hline
\end{tabular}


Table 4 shows that only the number of species in the community and the average cell biomass where not influenced by the fluctuating environmental factors.

However two very strong factors having positive influence on species development were: temperature - influencing the total community biomass and the number of diatom specie, and the concentration of nitrates which causes an increase in the total number of cells. Another mildly influencing factor is the TDS which increases the diversity of green algae. The total influences of all the above mentioned factors are caused by either climate (temperature) or anthropogenic activity (TDS, $\mathrm{NO}_{3}$ ).

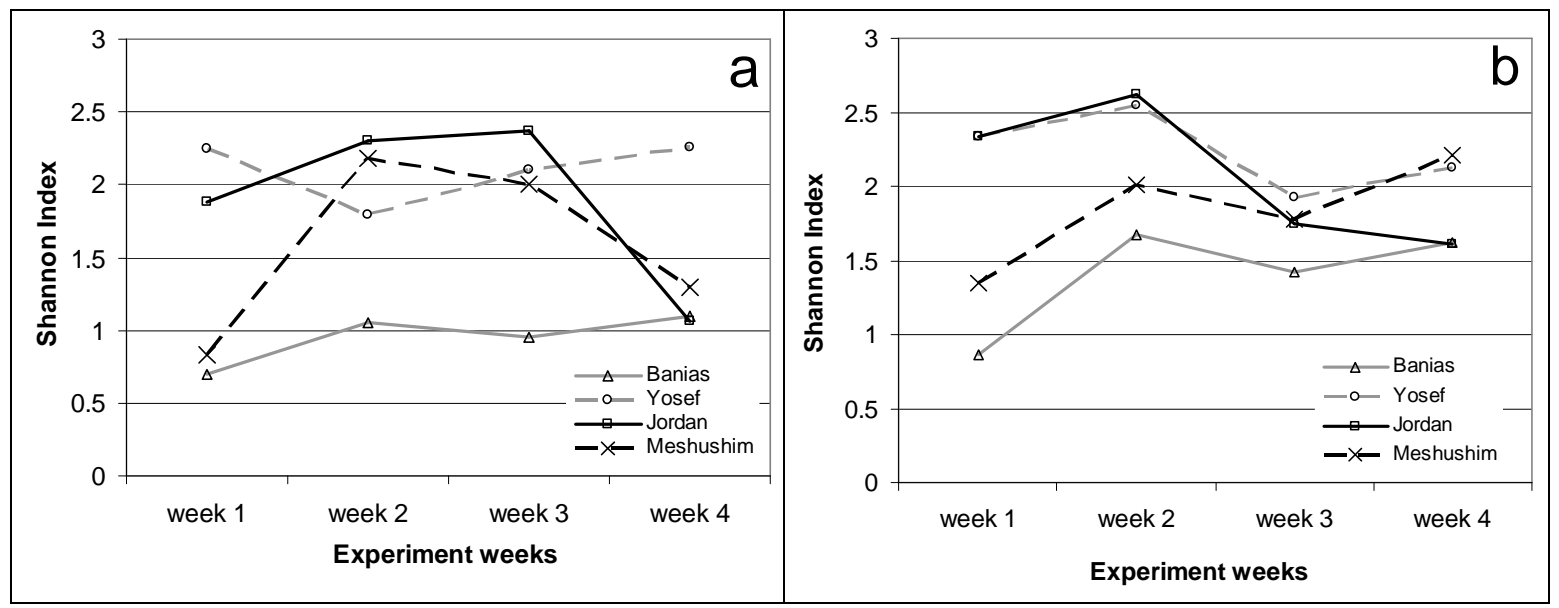

Figure 10. Changes of the Shannon index for all experimental stations during the summer and winter experimental periods - $a$ : winter; $b$ : summer

During the summer experimental period the Shannon index for each station was registered. In Fig. 10 it can be seen that the initial values of the index are different and are highest in the Jordan and Yosef stations. When comparing the obtained index values with the number of developing species for each of the stations, we find strong positive correlations - high index values correlate with high species numbers. During the experiment, index values in the stations with relatively low species numbers - Banias and Meshushim - had a rising tendency. However, at the species richer Yosef and Jordan stations, we registered an index lowering tendency. Since the Shannon index reflects the structural complexity of the present community we can conclude that: the break in the development of communities represented by the highest structural complexity was achieved on the second week for all stations. The overall rising tendency from the second week till the end of the experiment for all stations, points to rising complexity in the communities structures. This correlates to the processes of stabilization and self-purification.

Similarly during the winter experimental period the Shannon index for each station was registered. In Fig. 10 initial Shannon index levels in the Banias where and remained the lowest with only slight changes during the entire experiment. In the Jordan and Yosef stations we observed similar and high initial index levels However, communities' development was quiet the opposite for these two. Community structure at the Yosef station became more complex towards the end of the experiment while at the Jordan station the index dropped till it reached the value of 1 suggesting the community became poor with overall low number of species (Fig. 8a). At the Meshushim station the community significantly developed right until the second week reaching highly 
complex community structure Fig. 10. Afterwards and till the end of the experiment the Shannon index declined.

When comparing the changes of the Shannon index with changes in cell/biomass values we find that the community's high structural complexity is achieved due to the development of small cell species (as for instance in the Jordan station Fig. $4 a$ and Fig. 10a). This type of change indicates that the community is influenced by some stress impacts.

\section{Conclusion}

As can be seen from the above listed data and calculations, water temperature during the experimental period was typical for the winter $\left(11-19^{\circ} \mathrm{C}\right)$ and summer $\left(24-32^{\circ} \mathrm{C}\right)$ seasons. During the summer period the $\mathrm{pH}$ was alkaline while in the winter it declined below 7.0.

Nitrates concentration was higher during the summer especially at the Meshushim station; however it declined during the experiment as a result of the algal activity.

TDS values stabilized on the $2^{\text {nd }}-3^{\text {rd }}$ weeks of both experiments. The demineralization process reflects the water quality and is related to the activity of the algal communities. We can see that during the summer experiment a peak in the TDS values was reached on the third week at the Jordan and Meshushim stations and on the fourth week in the Banias and Yosef stations. The lowering of TDS values reflects the self-purification processes. Stabilization of the parameters in the ecosystem at each of the stations confirms that the self-purification process came to an end. The peak points to the self purification proccess which was more noticeable in the winter.

Algal diversity found on glass slide accretions in each of the experimental pools contained about 15-25 species for each of the pools. Algal communities where richer in the summer in all stations and contained mainly Diatoms during the winter and equal proportions of diatoms and green algae during the summer. Only the Banias station winter community was dominated by the green algae.

During the winter experiment at the Banias and Jordan stations maximal diversity was reached by the $3^{\text {rd }}$ week and in the Yosef and Meshushim stations by the $4^{\text {th }}$ week.

During the summer experiment maximal diversity was reached at the Banias and Meshushim stations by the $2^{\text {nd }}$ week, in the Jordan station by the $3^{\text {rd }}$ week and at the Yosef station there were two peaks on the $2^{\text {nd }}$ and the $4^{\text {th }}$ weeks. This implies that in the upper part of the basin (Banias station) during the summer the self-purification activity is higher. The Yosef and Meshushim stations were under anthropogenic influence so their diversity had a constant growing tendency till the end of the experiment. Alternatively at the Jordan station diversity stability was reached on the $3^{\text {rd }}$ week. These observations lead us to the conclusion that species richness grows in proportion to the anthropogenic influence on one hand and the intensity of the self-purification process on the other. Moreover the self-purification process proceeds faster in conditions of high temperature and high solar radiation - during the summer.

Algal abundance and biomass in all stations were ten times higher during the summer experiment in comparison to the winter experiment, due to the increased activity.

At the same time cell sizes were smaller in the summer communities. When comparing with species diversity (Fig. $6 b, 7 b, 8 b, 9 b$ ) we see that the high cell numbers found in the summer communities are comprised mostly of new small celled green algal 
species. Therefore we can conclude that: the speed with which algal encrustation is formed is influenced by temperature and solar radiation.

According to our calculations of the non parametric structural index of Shannon we can conclude that high Shannon index values correlate with species rich communities in both winter and summer experiments.

Overall, the experimental study showed that artificial colonization of substrates by algae takes about 2-3 weeks. Colonization is more active during the summer as a result of the formation of small celled green algae which growth is promoted by high temperatures and high solar radiation conditions. As found via the Multivariate statistical analysis- the important factors influencing algal activity are $\mathrm{pH}$ and Total Dissolved Solids concentration (major factors in water quality assessment). A detailed observation of the self-purification process can be conducted by monitoring diversity dynamics, cell counts, and biomass.

Acknowledgements. We thank Moti Tavassi, who collaborated in collecting algal samples from the Upper Jordan River. This work has been partially funded by the Israel Ministry of Absorption.

\section{REFERENCES}

[1] Ács, É., Reskóné, N.M., Szabó, K., Taba, G.Y., Kiss, K.T. (2005): Application of Epiphytic Diatoms in Water Quality Monitoring of Lake Velence - Recommendations and Assignments. - Acta Botanica Hungarica 47(3-4): 211-223.

[2] Barinova, S.S., Medvedeva, L.A. \& Anissimova, O.V. (2006): Diversity of Algal Indicators in Environmental Assessment. - Pilies Studio, Tel Aviv. (In Russian); http://herba.msu.ru/algae/materials/book/title.html

[3] Cardoso, A.C., Solimini, A.G., Premazzi, G. (2005): Report on Harmonisation of Freshwater Biological Methods. - EUR 21769 EN, European Communities.

[4] Charles D.F., Knowles, C., Davis, R.S. (eds) (2002): Protocols for the analysis of algal samples collected as part of the U.S. - Geological Survey National Water-Quality Assessment Program. Patrick Center for Environmental Research-Phycology Section, The Academy of Natural Sciences of Philadelphia. Report No. 02-06.

[5] European Parliament (2000): Directive 2000/60/EC of the European Parliament and of the Council establishing a framework for Community action in the field of water policy. Official Journal L327: 1-72.

[6] Good, I.J. (1953): The Population Frequencies of Species and the Estimation of Population Parameters. - Biometrika 40: 237-264.

[7] Hillebrand, H., Dürselen, C.-D., Kirschtel, D., Pollingher, U., Zohary, T. (1999): Biovolume Calculation for Pelagic and Benthic Microalgae. - Journal of Phycology, 35(2): 403-424.

[8] King, R.S., Richardson, C.J. (2003): Integrating Bioassessment and Ecological Risk Assessment: An Approach to Developing Numerical Water-Quality Criteria. Environmental Management 31(6): 795-809.

[9] PhycoTech (2007) - Technical Approach. http://www.phycotech.com/technical.html 